\title{
Evolution of subcutaneous allergen immunotherapy (part 1): from first developments to mechanism-driven therapy concepts
}

\author{
Ludger Klimek · Randolf Brehler · Eckard Hamelmann · Matthias Kopp · Johannes Ring • Regina Treudler • \\ Thilo Jakob - Margitta Worm - Oliver Pfaar
}

Received: 12 June 2018 / Accepted: 27 August 2018 / Published online: 15 April 2019

(C) The Author(s) 2019

\begin{abstract}
Background Subcutaneous allergen immunotherapy (SCIT) is the classic causal treatment method for IgEmediated allergic respiratory disease. A growing understanding of the fundamentals of immunological mechanisms sets the path for further clinical improvement of this treatment. Innovations in SCIT comprise both treatment schedules and new forms of allergen extracts applied. Nonmodified allergen preparations in the form of aqueous or physically coupled (semidepot) extracts, as well as chemically modified allergens (allergoids) are currently on the market for SCIT in Germany. However, to date the clinical documenta-
\end{abstract}

L. Klimek · Prof. Dr. O. Pfaar $(\bowtie)$

Center for Rhinology and Allergology, Wiesbaden, Germany oliver@pfaar.org

\section{R. Brehler}

Department of Dermatology, Münster University Hospital, Münster, Germany

\section{E. Hamelmann}

Clinic for Pediatric and Adolescent Medicine, Evangelical Hospital (EvKB), Bielefeld, Germany

Ruhr Allergy Center (ACR), Ruhr University Hospital Bochum, Bochum, Germany

\section{Kopp}

Pediatric Pulmonology and Allergology Unit, Pediatric and Adolescent Medicine, Schleswig-Holstein University Hospital, Lübeck, Germany

Airway Research Center North (ARCN), Member of the German Center for Pulmonary Research (Deutsche Zentrum für Lungenforschung, DZL), Borstel, Germany

\section{J. Ring}

Department of Dermatology and Allergology am Biederstein, Technical University of Munich, Munich, Germany tion of SCIT products in clinical studies is heterogeneous.

Methods A selective literature search was conducted in PubMed and Medline, and recent publications in German-language journals not available in these literature databases were also analyzed. This literature search comprised original and review articles both in German and in English.

Results SCIT is a long-established and well-documented treatment method for inhalant and insect venom allergies, with its efficacy and safety demonstrated in both the adult as well as in the pediatric population. In line with the German Therapy Allergen

\section{R. Treudler}

Department and Outpatient Clinic for Dermatology and Allergology, Leipzig University Hospital, Leipzig, Germany Leipzig Interdisciplinary Center for Allergology (LICA), Leipzig, Germany

T. Jakob

Department of Dermatology and Allergology, Gießen and Marburg University Hospital (UKGM), Gießen site, Justus-Liebig University Gießen, Gießen, Germany

\section{Worm}

Department of Dermatology, Venereology, and Allergology, Charité-University Hospital Berlin, Campus Mitte, Berlin, Germany

\section{Prof. Dr. O. Pfaar}

Department of Otorhinolaryngology, Head and Neck Surgery, Universitätsmedizin Mannheim, Medical Faculty Mannheim, Heidelberg University, Mannheim, Germany

Department of Otorhinolaryngology, Head and Neck Surgery, Section of Rhinology and Allergy, University Hospital Marburg, Phillipps-Universität Marburg, Baldingerstraße, 35043 Marburg, Germany 
Ordinance (TAV) several products for SCIT are currently being investigated in clinical trials. Treatment schedules are continuous year-round (perennial), preseasonal, and combined pre-/coseasonal. The initial up-dosing phase can be performed with standard, cluster or rush procedures. SCIT is particularly well established for frequently occurring inhalant allergens such as pollen from grasses, Betula sp. (birch, alder, hazel), house dust mites (Dermatophagoides sp.), and insect venoms (bee and wasp venoms). However, good data are also available for a number of other therapeutic allergens, e.g., weed pollen such as ragweed, mugwort, etc., molds, e.g., Alternaria, Cladosporium, etc., storage mites, and animal dander (e.g., cat). Moreover, further clinical investigations on new indications such as treatment effects on e.g., oral allergy syndrome or atopic dermatitis are currently underway.

Conclusion When adequately administered by physicians with allergological expertise, SCIT preparations are safe, well-tolerated, and clinically effective.

Keywords Allergic rhinitis - Insect venom allergy ·

Allergen immunotherapy $\cdot$ Subcutaneous immunotherapy $\cdot$ SCIT

\section{Abbreviations}

$\begin{array}{ll}\text { AIT } & \text { Allergen immunotherapy } \\ \text { APC } & \text { Antigen-presenting cell } \\ \text { AR } & \text { Allergic rhinitis } \\ \text { ARIA } & \text { Allergic rhinitis and its impact on asthma } \\ \text { CpG-ODN } & \text { CpG oligodeoxynucleotides } \\ \text { DCs } & \text { Dendritic cells } \\ \text { EAACI } & \text { European Academy of Allergy and Clini- } \\ & \text { cal Immunology } \\ \text { IFN } & \text { Interferon } \\ \text { IL } & \text { Interleukin } \\ \text { LC } & \text { Langerhan's cell } \\ \text { LPS } & \text { Lipopolysaccharides } \\ \text { MPL } & \text { Monophosphoryl lipid A } \\ \text { MS } & \text { Medication score } \\ \text { OR } & \text { Odds ratio } \\ \text { PAMP } & \text { Pathogen-associated molecular patterns } \\ \text { PEI } & \text { Paul Ehrlich Institute } \\ \text { PRR } & \text { Pattern recognition receptors } \\ \text { QoL } & \text { Quality of life } \\ \text { RQLQ } & \text { Rhinoconjunctivitis quality of life ques- } \\ & \text { tionnaire } \\ \text { SCIT } & \text { Subcutaneous immunotherapy } \\ \text { SLIT } & \text { Sublingual immunotherapy } \\ \text { SMS } & \text { Symptom and medication score } \\ \text { SS } & \text { Symptom score } \\ \text { TAV } & \text { Therapy Allergen Ordinance } \\ \text { TGF } & \text { Transforming growth factor } \\ \text { TLR } & \text { Toll-like receptor } \\ \text { Treg } & \text { Regulatory T cell } \\ \text { VIPs } & \text { Virus-like particles } \\ & \end{array}$

\section{Introduction}

Besides allergen avoidance measure, allergen immunotherapy (AIT) remains the only causal treatment options available for IgE-mediated allergic diseases such as allergic rhinoconjunctivitis or allergic asthma. The underlying mechanism of AIT include the induction of specific (blocking) antibodies as well as tolerance-inducing cells and immunomodulators. The activation of regulatory $\mathrm{T}$ cells (Treg) inhibits the $\mathrm{T}$ cell-mediated activation of specific $\mathrm{B}$ and T-cells. Treg cells migrate from the site of allergen application into the lymph nodes and produce e.g., both interleukin (IL)-10 and transforming growth factor (TGF)$\beta$, aimed to blunt inflammation.

Since the pioneering achievements of Noon and Freeman more than 100 years ago, both unmodified (semidepot) extracts as well as chemically modified extracts (allergoids) are currently marketed in Europe by different manufacturers for subcutaneous allergen immunotherapy (SCIT) [1].

Adjuvants in SCIT comprise e.g., aluminum hydroxide $\left(\mathrm{Al}(\mathrm{OH})_{3}\right)$, microcrystalline tyrosine (MCT) or tolllike receptor (TLR)-4 agonist monophosphoryl lipid A (MPL) and clinical efficacy has been demonstrated for different of these innovative agents [2]. To date, adjuvanted products in AIT only are marketed for the subcutaneous route. Further innovations not marketed already include e.g., CpG-oligodeoxynucleotides (CpG-ODN), a class of synthetically produced singlestrand DNA oligonucleotides with a high CpG-motif content or so-called virus-like particles (VIPs) as capsid proteins of viruses or bacteriophages. The latter do not contain viral RNA or DNA and are therefore unable to replicate, and this principle has already been investigated in preliminary studies $[3,4]$.

Clinical studies have also been conducted with recombinant grass pollen, birch pollen, and cat allergen proteins for SCIT. As part of further developments, these were further modified as hypoallergenic variants by modifying their molecular folding. It is hoped that, by reducing IgE binding sites, lower immunoglobulin E (IgE) reactivity will be achieved, which should result in a reduction in the rate of adverse effects. However, increases in immunological effectiveness by means of other modifications are also conceivable.

A challenge is posed by the immense costs of developing new preparations, which-against the backdrop of the considerable research efforts for the Therapy Allergen Ordinance (TAV) - hamper new innovations of immunologically altered products to some extent.

Nevertheless, the following outlines some promising achievements and further paths in SCIT development.

\section{Methods}

A selective literature search was conducted in PubMed and Medline, and recent publications in German- 
language journals not available in these literature databases were also analyzed. This analysis included original and review articles both in German and in English. Synonyms as well as translations into English were taken into account in the selection of suitable search terms in the German language, with Boolean operators AND, OR using truncations and wildcards and the following selection of terms: allergic rhinitis; bronchial asthma, venom, insect venom allergy, wasp venom allergy, bee venom allergy, allergy; inhalant allergy; immunotherapy, hyposensitization; desensitization; subcutaneous immunotherapy, sublingual immunotherapy, therapeutic allergens.

\section{Historical development of SCIT}

Allergen immunotherapy (AIT) has been in use for over 100 years and, from a historical perspective, is based on the premise that a protective effect can be achieved by administering small quantities of a harmful substance [5]. It was described for the first time in history in relation to King Mithridates of Pontus, who feared being poisoned [6].

A further source can be seen in Samuel Hahnemann's homeopathy founded on the basic principle of “similia similibus." However, AIT's most important root lies in the principle of vaccination, as introduced in 1798 by Eduard Jenner, who administered cow pox (Vaccinia) in order to prevent small pox (Variola vera) [6]. In 1807, Bavaria was the first state to enact a law making "preventive smallpox vaccination" compulsory.

In 1911, the researchers Leonard Noon and John Freeman (the latter continuing research following Noon's early death), succeeded in carrying out "prophylactic inoculation" with pollen extracts, which resulted in a clear reduction in ocular and nasal symptoms [7]. Noon and Freeman were influenced by the experimental work of Alexandre Besredka, who conducted similar experiments on animals using the term "anti-anaphylaxis" [6].

The method subsequently spread in the wake of the considerable immunological advances with active vaccinations, as well as passive immunizations, such that it can be found as a standard procedure in early allergology textbooks dating back to the 1920s and 1930s [6].

Early prospective clinical studies were carried out in the 1950s and are closely linked to the name William Frankland [6]. Attempts were made in the 1970s to alter allergen extracts by means of chemical modification using formaldehyde or glutaraldehyde or by polymerization to produce so-called "allergoids", which were believed to be more effective with fewer side effects [6]. At the same time, different adjuvants were used, some of which were meant to act as depot mediators as well as amplifiers of the immune response. Today, aluminum hydroxide, L-tyrosine, and MPL are used in commercial extracts to this end. Fur- thermore, polyethylene glycol-coupled allergens and nucleotides $(\mathrm{CpG})$ have also been used as adjuvants in studies [6].

For decades, subcutaneous administration was the only accepted mode; indeed, a virtual "war of faith" was waged at the various congresses, with fierce debates between the advocates of subcutaneous and those of "oral hyposensitization." At the end of the 1980s, the mode of oral administration was largely abandoned and replaced by sublingual administration. A sufficient number of studies, some of which were performed excellently, particularly for grass, birch, ragweed, and house dust mites, are now available for sublingual immunotherapy (SLIT), both as drops and tablets, and demonstrate its effectiveness.

\section{Mechanisms of SCIT}

The effect of AIT on allergen-specific TH2 cells and Tregs appears to be crucial to modulating the immune response.

Whilst of the three allergen-specific T-cell types (TH1, TH2, and Treg), Treg predominates in healthy nonallergic individuals, $\mathrm{TH} 2$ cells predominate in allergy sufferers [8]. However, T-cell tolerance is largely mediated by allergen-specific Treg, which suppresses the proliferation and cytokine production of peripheral T-cells against the respective allergen. There are two main groups of Tregs: Firstly, the physiologically occurring $\mathrm{CD}^{+}{ }^{+} \mathrm{CD} 25^{+} \mathrm{Foxp}^{+}$-nTregs that are formed in the thymus and which trigger inhibition via a cell contact-dependent mechanism; and secondly, the induced iTregs such as the Tr1 cells, which are characterized by high production of IL-10 (in addition to interferon (IFN)- $\gamma$ ). Peripheral $\mathrm{T}$ cell tolerance, by inducing Treg, has been demonstrated as an essential mechanism for the efficacy of SCIT [8]. CD4+-T cells in the peripheral blood of SCIT-treated patients react less to the allergen as early as 1 week following treatment initiation. Allergen-specific proliferation and cytokine production were reduced and an increase in IFN- $\gamma$ production consistent with a shift in the TH1/TH2 equilibrium towards TH1 was induced [8, 9]. Moreover, SCIT also inhibits induction of the important co-stimulatory molecule, inducible co-stimulator (ICOS), which is particularly important for TH2 effector cells [10].

However, the most important mechanism appears to be SCIT's induction of Treg $[9,11]$. Allergen-specific IL-10- and TGF-ß-producing $\mathrm{T}$ cells of this kind are detectable as early as 1 week after SCIT initiation and even more so after 8 weeks $[9,12,13]$. The significance of these cells has now been demonstrated, and the suppression of IL-10 and TGF- $\beta$ by neutralizing antibodies partially eliminates their effect $[9,12,13]$. The $\mathrm{CD}^{+}{ }^{+} \mathrm{CD} 25^{+}$nTreg in allergy sufferers are functionally impaired $[8,14,15]$.

Patients in whom nTreg are completely absent due to a mutation in the transcription factor Foxp3, 
which is important for nTreg (IPEX syndrome: immune dysregulation, polyendocrinopathy, enteropathy, X-linked), develop high serum IgE levels, marked eosinophilia, and allergies.

SCIT primarily activates local antigen-presenting cells (APC; e.g., dendritic cells, DC). They release in particular IL-10 and TGF-ß. Both cytokines can have a local anti-inflammatory effect and are able to inhibit $\mathrm{T}$-cell proliferation. In addition, the release of IL-10 serves to reinforce the production of blocking IgG antibodies. Upon activation of new-and boosting of existing - antibodies that block the allergen-mediated immune response, primarily IgG antibodies that are able to prevent the binding of IgG allergen complexes to B cells and DCs are formed.

The cytokines released locally also attenuate local mast cell activity and the activation of other effector cells that contribute to allergic inflammation.

It has been shown that SCIT leads to a reduction in IL-4-dependent allergen-specific IgE production and an increase in allergen-specific IgG production (particularly IgG4) $[8,9,16]$. The induced IgG antibodies compete with IgE antibodies for the epitopes on the allergen, thereby exerting a blocking effect. This blocking activity is independent of the quantity of IgG antibodies [17]. However, the capacity of IgG antibodies to block IgE antibodies is subject to considerable individual variation.

Following allergen exposure, antigen-presenting cells (APC) are able to steer the immune response towards TH1, and thus towards immunotolerance [18], and are likely crucial to the effect of SCIT.

SCIT not only reduces mucosal mast cells [19], but also inhibits the release of numerous mediators following allergen stimulation of basophils and mast cells. The inhibition of mediator release is partly IL-10-dependent; IL-10 also directly inhibits IgE-dependent activation of mast cells and their cytokine production $[8,20]$.

As a result, inflammatory cells such as eosinophilic and neutrophil granulocytes migrate to the affected mucosa to a far lesser extent.

\section{Quality of therapeutic extracts}

AIT products are generally difficult to compare due to their heterogeneous composition. To date, the characterization and standardization of allergen extracts has been carried out according to company-specific standards. Even if the concentration of major allergens is stated, this still does not permit a direct comparison of preparations from different manufacturers, and no direct conclusions on their potential efficacy can be drawn, since uniform analytical methods are not used to analyze major allergens and most allergen extracts contain several major allergens (sometimes unavoidably).

\section{Performance of and treatment schedules for SCIT}

Recommendations on the practical implementation of SCIT are published in national and international guidelines [1, 21-23]. Allergens in depot form are primarily used for AIT with aeroallergens, with aluminum or tyrosine serving as allergen carriers, thereby delaying allergen release.

In principle, native allergens or allergoids can be used for SCIT. In terms of their three-dimensional structure, allergoids are modified molecules or allergen multimers. The aim of modification is to reduce IgE-binding epitopes (generally conformation epitopes) while preserving $\mathrm{T}$ cell epitopes (generally sequential epitopes).

Clinical studies on the efficacy of allergoids are available for grass pollen [24-26], tree pollen [27], and mite [28] extracts.

Allergoids usually have a shorter dose escalation phase, with the maintenance dose being reached within a few treatment days of treatment initiation. Dose escalation schedules for native allergens are generally significantly longer-up to 3 months in the case of classic treatment (see below).

Depending on the preparation, treatment can be carried out year-round or preseasonally; both treatment schedules are approved for some allergoids. The study by Tworek et al., which shows perennial treatment to be significantly superior compared with preseasonal treatment in the third year of treatment, provides a useful comparison of the different treatment schedules [29].

Essentially, there are a number of variations that can be considered for the performance of different SCIT treatment schedules:

- Continuous, year-round (perennial) treatment

- Preseasonal treatment (prior to the start of the pollen season)

- Combined pre-/coseasonal treatment (e.g., 4-6 months prior to and during the season)

- Preseasonal short-term treatment with only a few (e.g., 4-7) injections out of season

SCIT treatment is usually divided into two phases: the (initial) build-up phase and the maintenance phase. The maintenance dose should be found during the build-up phase. Once the maintenance dose has been reached in the build-up phase, injection intervals can be prolonged to 4-8 weeks, depending on the preparation. SCIT is then performed with this maintenance dose over a period of at least 3 years. The individual characteristics of each preparation, as well as each patient, must be taken into consideration. Individual treatment schedules are now available for the various allergens and for patients' different treatment preferences; these schedules can be tailored, in consultation with the patient, to his or her needs.

Preseasonal short-term therapy is the shortest form of SCIT and is only used to treat inhalant allergies to 
pollen. In principle, it is a special form of the treatment discussed here, since it essentially corresponds to a build-up phase without a subsequent maintenance phase. To this end, SCIT is initiated in a timely manner prior to the start of the pollen season. Once the patient's maximum dose or individual maintenance dose is reached, this is only administered until the onset of pollination. Treatment is then discontinued (depending on the preparation, between four and seven injections are scheduled at weekly intervals).

As such, preseasonal short-term SCIT is particularly suitable for pollen-allergic patients for whom lower time requirements are a priority.

Cluster immunotherapy arose from the aim to reach the maintenance dose in the shortest possible period of time. Therefore, cluster immunotherapy involves the administration of a series (=cluster) of between two and three cumulative SCIT injections per treatment day. This makes lower time demands on the patient.

In the case of booster immunotherapy, a short dose escalation schedule is used over a period of a few weeks following previously completed SCIT several years before. Therefore, SCIT is suitable for patients who have already received AIT in the past and in whom the effect has subsided and symptoms have recurred [30]. Ultra-short booster SCIT has been shown to be effective in grass pollen-allergic individuals [30].

\section{Efficacy of commercial SCIT preparations in clin- ical trials}

Documentation on the clinical efficacy of SCIT in allergic rhinoconjunctivitis is based on numerous double-blind placebo-controlled (DBPC) studies; however, these are highly heterogeneous in terms of scope and quality [1, 31]. A number of examples of published DBPC studies on the most relevant inhalant allergens in Central Europe are presented below. In particular, the S2k guideline on AIT published in Germany refers to an excellent overview of the available evidence on the AIT preparations obtainable in Germany, as well as SCIT preparations [1] as follows: studies on TAV allergens published in this context, as well as further information and study details, are compiled in a table in the guideline Appendix, which is updated biannually and published on the homepage of the German Society for Allergology and Clinical Immunology (Deutsche Gesellschaft für Allergologie und klinische Immunologie, DGAKI; http:// www.dgaki.de/leitlinien/s2k-leitlinie-sit/). As such, it is always based on the current state of knowledge and provides the reader with sufficient and evidence based support in their decision to perform AIT, as well as on the selection of preparations for SCIT. The lack of comparability between preparations makes it necessary to review each individual AIT preparation in robust efficacy and safety studies [1, 31]. This puts prescribing physicians in a predicament that requires them to be familiar with, and assess, the evidence.

The table provides the current approval status of individual products, an overview of studies approved by the authorities (according to the European Medicines Agency (EMA) registry: www.clinicaltrialsregister.eu), and the number of publications that meet the following evidence criteria (modified to World Allergy Organization, WAO) [32]:

1. Standardized allergen extract with dose specification

2. Randomized DBPC study design

3. A combined symptom and medication score (SMS) and/or two individual scores (symptom score (SS) and/or medication score (MS)) are provided

4. Data on statistical analysis, statistically significant outcome

5. Treatment efficacy is at least $20 \%$ higher compared with placebo

A harmonization of AIT studies is sought at both a national and an international level [33]. However, the efficacy of the various allergen products can only really be compared if different products are used directly in the same study. It appears unlikely at present that head-to-head studies of this kind will be conducted in the foreseeable future.

Marketing authorisation can be obtained for AIT preparations by applying to the relevant authorities. AIT preparations that had already obtained official approval before the TAV came into force demonstrated their efficacy in studies that met approval requirements at that time. These preparations do not need to be re-assessed in new studies following the TAV prerequisites, but retain instead their long-term marketability. Since the studies conducted in the past do not meet the WAO criteria stipulated for inclusion in the guideline tables, the table includes in particular older authorized products for which no studies are listed despite the fact that studies exist.

All the above considerations apply only to AIT with frequently occurring allergens for which the TAV is valid (species of the family Poaceae, with the exception of Poa mays; Betula sp., species belonging to the birch genus; Alnus sp., species belonging to the alder genus; Corylus sp., species belonging to the hazel genus; Dermatophagoides sp., species belonging to the house dust mite genus; and bee venom and wasp venom) [34]. For all other therapeutic allergens that do not fall into the above-mentioned groups (e.g., weed pollen, e.g., ragweed, mugwort, plantain, etc.; molds, e.g., Alternaria, Aspergillus, Cladosporium, etc.; storage mites; animal dander, e.g., cat), the current legal situation continues to make provision for prescriptions as individual formulations (so-called "named patient products") even following enforcement of the TAV.

Regulatory authorities chose this path for good reason: the studies with high patient numbers required 
for the approval of rare allergens are all but unfeasible simply on the basis of the number of patients needed. However, patients with allergies to rare allergens are equally as entitled to cause-oriented AIT therapy as are other patients. Preparations that are produced and marketed as individual formulations according to $\$ 21$ Section 2, $1 \mathrm{~b}$ of the German Medicinal Products Act (Arzneimittelgesetz, AMG) remain available to these patients for AIT.

\section{Grass pollen}

A DBPC study on 30 adolescent and adult grass pollen allergy sufferers (15- to 35-year-olds) investigated 3 -year SCIT with an unmodified grass pollen allergen extract and an initial rush dose [35]. A statistically significant improvement in conjunctival and nasal symptoms during the second and third grass pollen seasons compared with the placebo group was seen. Another large DBPC study using the same SCIT product at different doses included over 400 grass pollen allergy sufferers (United Kingdom Immunotherapy Study Group, UKIS; [36]). The higher dose, which is available in Germany, showed a significant improvement in symptom and medication scores in the first grass pollen season compared with placebo. Another DBPC study in adult patients also demonstrated efficacy [37]. A DBPC study conducted only on 39 children (aged 3-16 years) with grass pollenrelated allergic asthma using the same SCIT product showed that the asthma symptom and medication score had significantly improved in the second grass pollen season in the actively treated group compared with the placebo-treated group [38].

A DBPC study on 154 adult grass pollen-allergic individuals investigated SCIT with a chemically modified allergen extract (allergoid) and a purely preseasonal schedule over a 2-year period and found statistically significant efficacy during the first and second grass pollen seasons [24]. Another study with the same allergoid, which primarily investigated immunological mechanisms during SCIT in 15 adult patients, additionally found a degree of clinical efficacy (secondary parameter) [39].

A controlled study over a 7 -year period (3-5 years SCIT, 1-2 years follow-up) with a grass allergoid revealed a significant (55\%) reduction in the basophil response as early as after 1-2 years of treatment. Even after treatment completion, long-term clinical efficacy due to sustained suppression of the allergen-specific basophil response was demonstrated [40].

Yet another DBPC study on 121 grass pollen-allergic patients using a grass pollen allergoid showed that SCIT using an up-dosing cluster protocol over a 1-week period, followed by 1 year of treatment, is safe and, what is more, associated with a significant improvement in symptoms and anti-allergy drug requirements in the first grass pollen season [41]. Depigmented grass pollen allergoids were investigated in a DBPC SCIT study on 53 allergic patients, with significant clinical efficacy once again being demonstrated in the first year of treatment [42]. Another DBPC study investigating the same product, but with a rush dose escalation (whereby the maximum maintenance dose was already reached on the first day of treatment), followed by year-round treatment over a 2-year period, showed a significant improvement in SS as well as MS in the first and second grass pollen seasons in the actively treated group compared with placebo patients [26]. That particular study also included adolescent grass pollen allergic patients, in whom similar efficacy was demonstrated compared with the group including only adults. However, the difference compared with placebo was not significant, which can be explained by the lower patient number in this age group. A grass pollen allergoid containing an MPL adjuvant was investigated in another DBPC study based on a purely preseasonal treatment schedule (only four injections) in 141 grass pollen-allergic patients; statistically significant efficacy was seen in the grass pollen season following treatment [43]. Another DBPC study using the same preparation in over 1000 adult grass pollen allergy sufferers confirmed this result [25].

A total of 60 elderly patients ( $>65$ years) with seasonal grass pollen-related allergic rhinitis received 3 -year SCIT with another grass pollen allergoid in a DBPC; a statistically significant difference in the combined SMS was seen in the actively treated group compared with the placebo-treated group in the third grass pollen season [44].

\section{Early flowering tree pollen (birch, alder, and hazel)}

There are fewer studies on therapeutic extracts of early flowering tree pollen compared with SCIT studies using grass pollen extracts.

As part of a DBPC study on 49 adult birch pollen-allergic patients [45], 2-year SCIT was performed using an unmodified birch pollen extract (Betula verrucosa), with a significant improvement in allergic symptoms compared with the placebo group and significantly reduced anti-allergic medication use being observed as early as in the first birch pollen season. These differences were even more pronounced in the second season. Another study using the same compound investigated the safety and efficacy of cluster up-titration followed by a maintenance dose at 8-week intervals over an 11-month period. During the grass season, patients in the SCIT group exhibited significantly fewer rhinoconjunctival symptoms and significantly reduced anti-allergic drug requirements compared with the placebo group [46]. Another DBPC study evaluated the clinical efficacy of preseasonal short-term SCIT with seven injections of an unmodified mixed tree pollen extract in 111 patients [47]. During the birch pollen season, SCIT resulted in a significant improvement in nasal and bronchial symptoms compared with the placebo group. 
Another DBPC study investigated a modified depigmented birch pollen allergoid in 61 pediatric, adolescent, and adult patients with birch pollen allergy [48]. SCIT was performed over a period of 18 months. Following treatment, a significantly reduced combined SMS was seen in the active group compared with the placebo group in the second birch pollen season observed, whereas no significant difference was seen between the groups in the first birch pollen season while SCIT was still ongoing-and pollination was mild in that particular year. Since the proportion of children and adolescents was so low, no age group-specific analysis was performed. SCIT using a tree pollen allergoid with an MPL adjuvant was carried out in a further DBPC study on 84 adult patients sensitized to birch, alder, and hazel pollen [49]. SCIT was performed as preseasonal short-term treatment consisting of four injections at 1-week intervals. A significant improvement in the combined SMS was seen in the treatment group compared to placebo during the 4-week birch pollen season that followed treatment. A DBPC on 62 patients demonstrated that 18-month SCIT with a birch pollen allergoid resulted in a significant reduction in the clinical index score for ocular and nasal symptoms during the birch pollen season [50].

\section{House dust mites}

House dust mite allergy is a worldwide problem. Mites belonging to the Dermatophagoides genus are particularly relevant [51]. As a general rule, allergen extracts can be produced from purified mite bodies or culture extracts; the composition of extracts varies depending on the raw materials used [52-54]. Analyses of commercially available extracts have revealed large differences in composition. The quantitative ratio between Der $\mathrm{p} 1$ and Der $\mathrm{p} 2$ can vary considerably, and in some extracts important allergens are actually missing [55]. There are no dose-finding studies for SCIT using house dust mite extracts.

It was shown as early as in 1993 that the efficacy of SCIT with a house dust mite extract depends on the quantity of allergen injected. Although this study was not placebo-controlled, a comparison was made with a control group that did not receive injections. The allergen quantities administered were reported to be 10,000, 100,000, and 30,000 standard quality units (SQ-U) [56]. On the basis of this data, the preparation is still on the market at 100,000 SQ-U.

A five-arm dose-finding study tested a chemically modified house dust mite extract (allergoid) at four doses (6667, 20,000, 50,000, 100,000 AUeq/ml; AU, allergy unit) over 12 months to analyze its effect on titrated nasal challenge testing [57]. Results were statistically significant for the three highest allergen quantities.

A study on 136 patients evaluated five concentrations of a house dust mite allergen depot extract for its efficacy in relation to titrated nasal challenge testing following 17 weeks of treatment [58]. The extract's allergen concentration was given as skin prick test units. Compared with nasal challenge prior to treatment, a higher allergen concentration was required in all treatment groups in order to trigger a reaction; a significant effect was demonstrated only at the fourth highest dose.

A DBPC study with a mite allergoid documented a significant (64\%) improvement in SS in patients aged over 65 years compared with baseline. At 24 months, the SS reduction was $52 \%$ compared with the placebo group [59].

An open prospective study on children with mite allergy demonstrated a significant improvement in asthma classification as well as a reduction in asthma medication as early as after 8 months of treatment with a mite allergoid. An improvement in quality of life was also observed [60].

Numerous DBPC studies have investigated efficacy at the symptom and medication score level. The results from studies on SCIT with house dust mite allergens can be found in Table 1. Subcutaneous and sublingual immunotherapy with a house dust mite extract were compared with each other in a small study on 30 patients [61]. Each patient group comprised 10 patients. A depot extract at a dose of $500 \mathrm{TU} / \mathrm{ml}$ (transducing units per $\mathrm{ml}$ ) was administered subcutaneously, and the cumulative dose was reported as 21,885 TU D.p. and 21,885 TU D.f.; an extract with $1000 \mathrm{TU} / \mathrm{ml}$ was administered sublingually three times a week. The cumulative SLIT dose was reported to be 86,866.5 TU D.p and 86,866.5 TU D.f. The primary target parameters were SS and MS at 1 year. SCIT and SLIT significantly reduced SS and MS compared with baseline. Only the reduction in SS in the SCIT group was significant compared with the placebo group.

In a DBPC study in 55 patients suffering from allergic rhinitis/rhinoconjunctivitis and asthma a one year treatment with a depigmented polymerized allergen extract of Dermatophagoides pteronyssinus showed a statistically significant reduction of symptom score of $78 \%$ and medication score of $68 \%$. These findings were further substantiated by a statistically significant improvement of the bronchial provocation test in actively treated patients [62].

In a DBPC study in 54 patients suffering from allergic rhinitis/rhinoconjunctivitis and asthma a one year treatment with a depigmented polymerized allergen extract of Mite Mix (50\% Der. pter/Der. f) showed a statistically significant improvement of the bronchial provocation test. This finding was further substantiated by statistically significant reduction of the symptom score of $53.86 \%$ and medication score of $58.09 \%$ [63]. 
Table 1 Double-blind placebo-controlled studies on SCIT with house dust mite allergens

\begin{tabular}{|c|c|c|c|c|c|}
\hline Author & $\begin{array}{l}\text { Randomized patients } \\
(n) / \text { patients evaluated } \\
(n)\end{array}$ & Maximum dose & Duration & $\begin{array}{l}\text { Primary target } \\
\text { parameter }\end{array}$ & Outcome \\
\hline Metzger 1981 [64] & $100 / 92$ & $\begin{array}{l}6000 \text { PNU (tyrosine-ad- } \\
\text { sorbed allergoid) }\end{array}$ & Five injections & SS, MS & $\begin{array}{l}\text { Significant reduction in SS and } \\
\text { MS }\end{array}$ \\
\hline Blumberga 2011 [65] & $54 / 42$ & 100,000 SQ-U & 3 Years & $\begin{array}{l}\text { Nonspecific BHR, } \\
\text { specific BHR }\end{array}$ & $\begin{array}{l}\text { No effect on nonspecific BHR, } \\
\text { significant effect on specific BHR }\end{array}$ \\
\hline Gallego 2010 [66] & $64 / 54$ & $\begin{array}{l}100 \text { HEPL (depigmented } \\
\text { allergoid) }\end{array}$ & 1 Year & SS, MS & $\begin{array}{l}\text { Significant reduction in SS and } \\
\text { MS }\end{array}$ \\
\hline Riechelmann 2010 [67] & $145 / 115$ & $\begin{array}{l}20,000 \mathrm{AU} / \mathrm{ml} \text { (allergoid, } \\
8 \mu \mathrm{g} \text { Der } \mathrm{p} 1,30 \mu \mathrm{g} \text { Der } \mathrm{p} \\
\text { 2/ml) }\end{array}$ & 1 Year & SMS & $\begin{array}{l}\text { Significant effect compared with } \\
\text { placebo }\end{array}$ \\
\hline Wang 2006 [68] & $132 / 129$ & 100,000 SQ-U & 1 Year & $\begin{array}{l}\text { Asthma symp- } \\
\text { toms and asthma } \\
\text { medication }\end{array}$ & $\begin{array}{l}\text { Significant reduction in symp- } \\
\text { toms and medication use }\end{array}$ \\
\hline Dokic 2005 [69] & 40 & Allergoid & 2 Years & VAS & $\begin{array}{l}\text { Significant effect compared with } \\
\text { placebo }\end{array}$ \\
\hline Varney 2003 [70] & $36 / 27$ & $\begin{array}{l}\text { 100,000 SQ-U (7 mg Der } \\
\text { p 1) }\end{array}$ & 1 Year & SS, MS & $\begin{array}{l}\text { Treatment SS: } 58 \% \text {, placebo SS: } \\
30 \% \text {, MS reduction not signifi- } \\
\text { cant }\end{array}$ \\
\hline Olsen 1997 [71] & $31 / 23$ & 100,000 SQ-U & 1 Year & Asthma SS/MS & $\begin{array}{l}\text { Significant reduction in SS and } \\
\text { MS }\end{array}$ \\
\hline \multirow[t]{2}{*}{ Ewan 1988 [72] } & $60 / 38$ & $100,000 \mathrm{BU}$ & 3 Months & VAS & Significant reduction \\
\hline & & $\begin{array}{l}\text { Dose achieved, mean } \\
17,000 \mathrm{BU}\end{array}$ & & NPT & \\
\hline Ameal 2005 [62] & $63 / 55$ & $\begin{array}{l}100 \mathrm{DPP} / \mathrm{ml} \text { depigmented } \\
\text { Der pter allergoid }\end{array}$ & $\begin{array}{l}12 \text { injections } \\
1 \text { year }\end{array}$ & SS, MS & $\begin{array}{l}\text { Significant reduction of SS and } \\
\text { MS }\end{array}$ \\
\hline Garcia-Robaina 2006 [63] & $64 / 54$ & $\begin{array}{l}100 \mathrm{DPP} / \mathrm{ml} \text { depigmented } \\
\text { Der pter/Der f allergoid }\end{array}$ & $\begin{array}{l}12 \text { injections } \\
1 \text { year }\end{array}$ & BPT & $\begin{array}{l}\text { Significant improvement of } \\
\mathrm{PD}_{20} \mathrm{FEV}_{1} \text { in BPT }\end{array}$ \\
\hline
\end{tabular}

\section{Storage mites}

Cross-reactivity between house dust mites and storage mites is low; the current literature reports only one DBPC study on the efficacy of SCIT with a storage mite extract.

The study investigated the efficacy of SCIT using a Lepidoglyphus destructor extract (maximum maintenance dose of 800 standard treatment units, STU) in 35 patients [73]. Patients were treated over a 12-month period. Sensitivity was determined at baseline and after treatment using skin tests, provocation tests, in vitro tests, as well as symptom and medication scores as efficacy parameters. A statistically significant effect on skin sensitivity and provocation tests (conjunctival provocation with allergen and nonspecific bronchial provocation with metacholine) was observed. Patients in the treatment group reported symptom improvement and reduced use of drugs effective against symptoms significantly more frequently compared with the placebo group.

\section{Ragweed pollen}

Ragweed pollen allergy is an immense problem in the US; sensitization prevalences to grass pollen and rag- weed pollen are approximately the same. The prevalence of these plants is also on the rise in Germany [74]; moreover, it is assumed that ragweed pollen allergy will increase dramatically in Europe due to climate changes [75].

Studies on AIT using ragweed pollen extracts have been published (Table 1); in this regard, large studies also meet the quality criteria stipulated for modern studies.

A phase 2B trial evaluated the efficacy of a ragweed pollen allergoid absorbed to tyrosine combined with an MPL adjuvant. The study randomized 95 patients to be treated with the test preparation, 40 to be treated with the allergen without an adjuvant, and 93 to be treated with placebo. Provocation in an environmental exposure chamber after four injections administered at weekly intervals had a significant effect compared with placebo, which was also superior to the effect of the allergen alone [76]. The larger published studies are summarized in Table 2.

\section{Mugwort pollen}

Allergy to mugwort pollen certainly plays a role in Europe, and cross-reactivity with ragweed pollen allergens is seen. A recent PubMed search also failed 
Table 2 Studies on SCIT with ragweed pollen

\begin{tabular}{|c|c|c|c|c|c|}
\hline Author & $\begin{array}{l}\text { Randomized patients } \\
(n) / \text { patients evaluated } \\
(n)\end{array}$ & Maximum dose & Duration & Effect on SS/MS & Outcome \\
\hline Metzger 1981 [64] & $100 / 92$ & $\begin{array}{l}6000 \text { PNU (tyrosine-ad- } \\
\text { sorbed allergoid) }\end{array}$ & Five injections & SS, MS & $\begin{array}{l}\text { Significant reduction in SS and } \\
\text { MS }\end{array}$ \\
\hline \multirow[t]{2}{*}{ Norman 1982 [77] } & $66 / 53$ & Allergoid $500 \mathrm{U}$ & 1 Year & SMS & $\begin{array}{l}\text { Significant reduction in SMS } \\
\text { using allergoid and allergen }\end{array}$ \\
\hline & & Allergen $500 \mathrm{U}$ & & & \\
\hline Grammer 1987 [78] & $81 / 68$ & $\begin{array}{l}125 \mathrm{AU} / \mathrm{ml} \text { (polymerized } \\
\text { allergen) }\end{array}$ & 15 Weeks & SS, MS & $\begin{array}{l}\text { Significant reduction in SS and } \\
\text { MS }\end{array}$ \\
\hline lliopoulos 1991 [79] & $41 / 21$ & $1.92 \mu \mathrm{g} \mathrm{Amb}$ a 1 & 8 Months & SMS & Significant reduction in SMS \\
\hline Brunet 1992 [80] & 27 & 3000 PNU & 9 Weeks & SS, MS, NPT & $\begin{array}{l}\text { Significant reduction in SS and } \\
\text { NPT }\end{array}$ \\
\hline Mirone 2004 [81] & $32 / 22$ & $7.2 \mu \mathrm{g} \mathrm{Amb}$ a 1 & $\begin{array}{l}1 \text { Year place- } \\
\text { bo-controlled, } \\
\text { then all pa- } \\
\text { tients treated }\end{array}$ & SS, MS & $\begin{array}{l}\text { Significant improvement com- } \\
\text { pared with placebo }\end{array}$ \\
\hline \multirow[t]{2}{*}{ Creticos 1996 [82] } & $77 / 64 / 53$ & $\begin{array}{l}4 \mu \mathrm{g} A m b \text { a } 1 \text { in the } 1 \mathrm{st} \\
\text { year }\end{array}$ & 1 Year/2 years & $\begin{array}{l}\text { Skin test, PEF, } \\
\text { Asthma medica- } \\
\text { tion }\end{array}$ & $\begin{array}{l}\text { Improvement in PEF, significantly } \\
\text { fewer rhinitis symptoms in the } \\
\text { 2nd year }\end{array}$ \\
\hline & & $10 \mathrm{~g}$ In the $2 \mathrm{nd}$ year & & Rhinitis symptoms & \\
\hline Patel 2014 [76] & $228 / 212$ & 6000 SU-Q plus MPL & $\begin{array}{l}\text { Four pre- } \\
\text { seasonal } \\
\text { injections }\end{array}$ & $\begin{array}{l}\text { SS on provocation } \\
\text { in provocation } \\
\text { chamber (PP) }\end{array}$ & $\begin{array}{l}48 \% \text { Improvement compared } \\
\text { with placebo }\end{array}$ \\
\hline
\end{tabular}

to find any DBPC studies on SCIT with mugwort pollen extracts in allergic rhinoconjunctivitis (keywords: "mugwort or artemisia and specific immunotherapy").

\section{Ash pollen/olive pollen}

Olive pollen is an important inhalant allergen in the Mediterranean region [83, 84]. SCIT using olive pollen extract is occasionally recommended in Germany as an option to treat patients with ash pollen allergy. Although the efficacy of SCIT with olive pollen extracts has been investigated in studies, these were not placebo-controlled [83, 84].

\section{Parietaria pollen}

In contrast to Mediterranean countries, allergy to Parietaria pollen is currently of no significance in Germany. Cross-reactivity with allergens in nettle pollen has been described.

A DBPC study investigated the efficacy of a Parietaria pollen extract adsorbed onto aluminum hydroxide [85]. A total of 57 patients were randomized; following 2 years of treatment, 22 patients were evaluated. Maintenance treatment consisted of $20 \mathrm{BU}$ (biological units) of allergen corresponding to $1.2 \mu \mathrm{g}$ Par j 1 administered subcutaneously. A significant effect on SS and MS was seen following 2 years of treatment.

A DBPC study on 30 patients investigated the efficacy of SCIT with Parietaria pollen over a period of 34 months. Both the SS and MS increased significantly in the control group, while, in comparison, no significant changes to these parameters were seen in the treatment group [86].

A DBPC on 35 patients with Parietaria pollen allergy received subcutaneous treatment for 1 year with an alginate-conjugated Parietaria pollen extract [87]. Analysis of 31 patients revealed a significant reduction in SMS.

A 1-year SCIT study using a Parietaria pollen allergoid (maintenance dose, 10,000 AUeq) demonstrated a significant effect on SS and MS compared with placebo. Altogether, the study was conducted over a 3 -year period. In the 2 final years, the original placebo group also received active treatment and, likewise, exhibited a clear improvement in SS and MS [88].

A Parietaria pollen allergoid was tested in 40 patients over a 1-year period. All patients included in this study received active SCIT in the second study year. Preseasonal treatment consisted of administering a cumulative dose of 24,500 TU. Investigators found a significant reduction in SS and a reduction in MS in the first year following treatment initiation [89].

\section{Cypress pollen}

Cypress pollen is an important aeroallergen in Asia and Mediterranean countries. Due to the rising prevalence of cypresses in parks and gardens, patients in Germany are becoming increasingly sensitized to cypress pollen. 
As part of a DBPC study, 40 European patients were subcutaneously administered with a cypress pollen extract (100 IR maintenance dose, maximum of $16.2 \mu \mathrm{g}$ Jun a 1) over a period of approximately 1.5 years. In all, 28 patients completed the study, while 12 patients discontinued the trial due to side effects, lack of efficacy, or personal reasons. A significant reduction in nasal symptoms was seen in the second year. Ocular symptoms were significantly reduced in both years. Although drug use was lower in the treatment group compared with the placebo group, the difference was not statistically significant [90].

\section{Cat allergen}

A European study that investigated the frequency of positive prick tests to a panel of nine aeroallergens found that the prevalence of sensitization to cat allergen came third with $8.8 \%$, after the frequency of sensitization to house dust mite and grass pollen. No large studies have been published on AIT with cat allergen.

A DBPC study on 28 patients with moderate to severe allergic rhinoconjunctivitis and asthma due to cat allergen investigated the efficacy of SCIT using a native cat depot preparation [91]. During the build-up phase, 11 injections were administered twice weekly. The maintenance dose aimed for was 100,000 SQ-U $(\triangleq 15 \mu \mathrm{g} \mathrm{Fel} \mathrm{d} \mathrm{1).}$

Intradermal testing and titrated conjunctival provocation with cat allergen were performed to investigate efficacy, followed by provocation testing (being in a home with cats and a defined aeroallergenic cat allergen level). Compared with the placebo group, a significant reduction was seen in symptoms upon being in a home with cats (reduction in SS from 61.6 \pm 9.1 to $17.1 \pm 7.6$ points in the treatment group and from $64.7 \pm 13.6$ to $62.1 \pm 10.0$ points in the placebo group). However, in addition to a reduction in sensitivity to cat allergen in skin testing, a simultaneous reduction in sensitivity to house dust mite allergen was also seen in the treatment group only-a phenomenon that defied explanation. Studies published on SCIT with cat allergens can be found in Table 3 .

\section{New approaches using cat allergen}

Fel $\mathrm{d} 1$ is the predominant major cat allergen. The intracutaneous administration of a mixture of overlapping Fel d 1 peptides was shown to be safe and effective in a phase 2 study: the efficacy of four 6 -nmol allergen injections was still evident at 1-year followup [94]. A phase 1 study on almost 1000 patients revealed an approximately $60 \%$ effect in the placebo group, which was comparable to that in the treatment group. This outcome is currently the subject of discussion. This unusually high placebo effect is difficult to explain [95, 96]. In that particular study at least, the efficacy of the cat peptide was not demonstrated.

\section{Dog allergens}

There are no large studies on SCIT with dog allergen in the recent literature.

\section{Horse allergens}

Similarly, no evidence on the efficacy of SCIT in horse dander allergy can be found in the recent literature.

\section{Mold allergens}

Alternaria and Cladosporium are important outdoor allergens worldwide. Penicillium and Aspergillus spp. are considered relevant indoor allergens; Aspergillus fumigatus colonizes the bronchial tract of asthma sufferers and causes allergic bronchopulmonary aspergillosis [97].

The prevalence of sensitization is subject to geographic variation: in Europe, a positive skin test with Alternaria and Cladosporium extract lies in the range

Table 3 Studies on SCIT with cat allergen

\begin{tabular}{|c|c|c|c|c|c|}
\hline Author & $\begin{array}{l}\text { Randomized patients } \\
(n) / \text { patients evaluated } \\
(n)\end{array}$ & Maximum dose & Duration & $\begin{array}{l}\text { Primary target } \\
\text { parameter }\end{array}$ & Outcome \\
\hline \multirow[t]{2}{*}{ Varney 1997 [91] } & \multirow[t]{2}{*}{28} & \multirow[t]{2}{*}{$\begin{array}{l}100,000 \mathrm{SQ}-\mathrm{U} \triangleq 15 \mu \mathrm{g} \\
\text { Fel d } 1\end{array}$} & \multirow[t]{2}{*}{3 Months } & $\begin{array}{l}\text { SPT, conjunctival } \\
\text { provocation }\end{array}$ & \multirow{2}{*}{$\begin{array}{l}\text { Significant improvement in all } \\
\text { parameters compared with } \\
\text { placebo }\end{array}$} \\
\hline & & & & $\begin{array}{l}\text { Symptoms during } \\
\text { time spent in } \\
\text { a home with cats }\end{array}$ & \\
\hline \multirow[t]{2}{*}{ Ohmann 1984 [92] } & \multirow[t]{2}{*}{17} & \multirow[t]{2}{*}{$6.3 \mathrm{U}$} & \multirow[t]{2}{*}{16 Weeks } & $\begin{array}{l}\text { Bronchial provo- } \\
\text { cation with cat } \\
\text { allergens }\end{array}$ & \multirow{2}{*}{$\begin{array}{l}\text { Lower sensitivity in bronchial } \\
\text { provocation test with cat } \\
\text { allergens, but not with } \\
\text { metacholine }\end{array}$} \\
\hline & & & & Exposure test & \\
\hline Taylor 1978 [93] & $10 / 10$ & $0.8 \mathrm{mg}$ Cat allergen & 3-4 Months & $\begin{array}{l}\text { Bronchial chal- } \\
\text { lenge with cat } \\
\text { allergen and his- } \\
\text { tamine }\end{array}$ & $\begin{array}{l}\text { Lower sensitivity to cat allergen, } \\
\text { but not to histamine in bronchial } \\
\text { challenge test }\end{array}$ \\
\hline
\end{tabular}


Table 4 Double-blind placebo-controlled studies on SCIT with Alternaria alternata

\begin{tabular}{|c|c|c|c|c|c|}
\hline Author & $\begin{array}{l}\text { Randomized patients } \\
\text { (n)/patients evaluated } \\
(n)\end{array}$ & $\begin{array}{l}\text { Maximum maintenance } \\
\text { dose }\end{array}$ & Duration & Primary target parameter & Outcome \\
\hline Kuna 2011 [99] & $50 / 45$ & $5000 \mathrm{TU} \triangleq 8 \mu \mathrm{g}$ Alt a 1 & 3 Years & SMS & $\begin{array}{l}63 \% \text { Difference in SMS between } \\
\text { placebo and treatment groups } \\
\text { after } 3 \text { years }\end{array}$ \\
\hline Tabar 2007 [104] & $28 / 23$ & $0.165 \mathrm{mg} \triangleq 0.1 \mu \mathrm{g}$ Alt a 1 & 1 Year & $\begin{array}{l}\text { Different parameters } \\
\text { investigated, primary } \\
\text { target parameter not } \\
\text { defined }\end{array}$ & $\begin{array}{l}\text { Improvement of some parame- } \\
\text { ters, both in the placebo and the } \\
\text { treatment group }\end{array}$ \\
\hline Kilic 2011 [105] & 16 & $?$ & 1 Year & $\begin{array}{l}\text { Bronchial challenge } \\
\text { with metacholine and } \\
\text { Alternaria }\end{array}$ & $\begin{array}{l}\text { Significant improvement after } \\
1 \text { year }\end{array}$ \\
\hline \multirow[t]{3}{*}{ Horst 1990 [106] } & \multirow[t]{3}{*}{$24 / 18$} & \multirow[t]{3}{*}{$2000 \mathrm{BU} \triangleq 1.6 \mu \mathrm{g}$ Alt a 1} & \multirow[t]{3}{*}{1 Year } & SMS & \multirow{3}{*}{$\begin{array}{l}\text { Treatment resulted in } \\
\text { a significant improvement in all } \\
\text { parameters }\end{array}$} \\
\hline & & & & Subjective score & \\
\hline & & & & Nasal challenge & \\
\hline
\end{tabular}

of $0.2-14.4 \%$ and $0-11.9 \%$, respectively, in 20 - to $44-$ year-olds. As such, mold spores represent an important group of inhalant allergens; however, the standardization of mold extracts is problematic. Depending on the culture medium used, cultured molds in particular show rapid somatic mutations, which affect their allergenicity. The range of allergens contained in extracts depends largely on the extraction method. Enzymes contained in extracts can destroy cellulosebased dialysis membranes in particular, thereby impairing the production process. If the focus is on proteins during isolation, important carbohydrate-rich allergens may be lost during preparation [98].

\section{Alternaria}

The efficacy of SIT using Alternaria extracts has been evaluated in a number of mostly small studies that failed to meet current clinical study criteria (no DBPC design, no underlying statistical model to estimate the case number needed, use of nonstandardized extracts, overly short follow-up period), with the exception of one study by Kuna et al. as outlined below [99]. A 2014 review concluded that there is a lack of randomized placebo-controlled studies demonstrating the efficacy of SIT using mold extracts, in particular Alternaria and
Cladosporium [98]. On the other hand, side effects, including systemic reactions, were not uncommon in open studies on SCIT with mold extracts [100-102]. A recent review also concludes that reliable studies on AIT with mold extracts are lacking. At present, therefore, only treatment with Alternaria alternata for allergic rhinitis and/or bronchial asthma can be recommended, since standardized extracts are only available for Alternaria [103].

The largest published study with a monocentric, prospective, randomized DBPC design investigated the effect of perennial treatment over a 3-year period; 45 of the 50 originally randomized children and adolescents with rhinoconjunctivitis and/or asthma due to Alternaria allergy were analyzed [99]. Maintenance treatment comprised administering injections of a maximum of $5000 \mathrm{TU} / \mathrm{ml}(8 \mu \mathrm{g} / \mathrm{ml}$ Alt a 1) every 4-6 weeks. The primary endpoint was combined SMS. No significant difference was seen between the placebo and treatment groups in the first year of treatment; in the second year, the difference was $38.7 \%$ and in the third year $63.5 \%$. This result is statistically significant. The reduction in symptoms was associated with a significant improvement in quality of life. No relevant side effects were reported. A recent Med-

Table 5 Double-blind placebo-controlled studies on SCIT with Cladosporium

\begin{tabular}{|c|c|c|c|c|c|}
\hline Author & $\begin{array}{l}\text { Randomized patients } \\
(n) / \text { patients evaluated } \\
(n)\end{array}$ & $\begin{array}{l}\text { Maximum maintenance } \\
\text { dose }\end{array}$ & Duration & $\begin{array}{l}\text { Primary target } \\
\text { parameter }\end{array}$ & Outcome \\
\hline \multirow[t]{3}{*}{ Dreborg 1986 [107] } & \multirow[t]{3}{*}{$30 / 30$} & \multirow[t]{3}{*}{$100,000 \mathrm{BU}$} & \multirow[t]{3}{*}{10 Months } & SMS & \multirow{3}{*}{$\begin{array}{l}\text { Significant improvement in BPT } \\
\text { compared with placebo }\end{array}$} \\
\hline & & & & SPT, CPT & \\
\hline & & & & BPT & \\
\hline Malling 1986 [108] & $23 / 22$ & $100,000 \mathrm{BU}$ & 5-7 Months & SMS & $\begin{array}{l}\text { Improvement in SMS compared } \\
\text { with placebo, but not in the } \\
\text { evaluation of SS and MS alone }\end{array}$ \\
\hline
\end{tabular}


line search yielded the monocentric DBPC studies on SIT using Alternaria extracts shown in Table 4.

\section{Cladosporium}

Small studies have also been conducted with Cladosporium extracts. DBPC studies are summarized in Table 5.

\section{Aspergillus}

There are no DBPC studies in the literature on the efficacy of Aspergillus extracts for SCIT.

\section{SCIT with insect venom}

Numerous insect species are able to cause local or systemic reactions with their sting. In central Europe, Hymenoptera such as honey bees (Apis mellifera) and wasps (in particular Vespula vulgaris and V. german$i c a$ ) are the most frequent triggers of clinically relevant reactions. Systemic anaphylactic reactions to insect stings are potentially life-threatening.

Subcutaneous administration is to date the only evidence-based mode of use when performing AIT with insect venom [109-111].

Ever since the experience gleaned by the working group around Lichtenstein, SCIT is now performed only with venoms from the above-mentioned insects and no longer with whole-body extracts [112].

SCIT with bee or wasp venom should be performed in patients that have experienced sting anaphylaxis involving respiratory and/or cardiovascular symptoms, in adult patients with immediate-type systemic sting reactions, irrespective of severity, as well as in patients with individual risk factors [109].

Now that bee and wasp venom preparations are available for diagnostic and therapeutic purposes, Hymenoptera venom allergy can be treated highly effectively. Appropriate SIT protects virtually all patients against repeat systemic sting reactions [109-111]. A recent systematic literature review and meta-analysis conducted by the European Academy of Allergy and Clinical Immunology (EAACI) in 15 international biomedical databases found 17 studies that met the inclusion criteria. This analysis confirmed that insect venom SCIT reduces the risk of severe sting reactions (odds ratio $(\mathrm{OR})=0.08$; 95\% confidence interval $(\mathrm{CI})$ 0.03-0.26). A meta-analysis revealed an improved disease-specific quality of life (QoL) of 1.41 (95\% CI 1.04-1.79) [110].

Aqueous allergen preparations as well as aluminum hydroxide-adsorbed depot extracts that can be injected subcutaneously are available for SCIT with insect venom [109, 111].

There is a wide range of treatment schedules for SCIT initiation and dose escalation, whereby the maintenance dose is reached within varying time periods [109, 111].
A distinction is made between two basic procedures:

- Rapid hyposensitization, whereby the maintenance dose is reached within hours to several days (ultrarush SCIT schedule) or after 3-5 days (rush SCIT schedule)

- Conventional hyposensitization, whereby the maintenance dose is reached within weeks to months

Particularly in the case of patients at risk of severe reactions, the build-up phase of hyposensitization should be performed in an inpatient setting.

Systemic anaphylactic reactions and subjective general symptoms may occur as side effects of SCIT, particularly in the initiation phase; severe reactions, however, are rare [109, 111]. Ultra-rush/rush SCIT performed in the inpatient setting has the advantage that the maintenance dose can be reached within only a few days, following which patients generally tolerate insect stings. The standard maintenance dose is usually around $100 \mu \mathrm{g}(200 \mu \mathrm{g}$ in specific cases) of insect venom [109, 111], injected at 4-week intervals.

Since the success of SCIT appears to be dose-dependent, patients for whom the usual maintenance dose is insufficiently effective can generally still attain full protection with a dose increase. As such, one can consider choosing an increased maintenance dose of $200 \mu \mathrm{g}$ every 4 weeks for patients with risk factors, particularly in the case of SCIT with bee venom [113]. In the case of concomitant wasp and bee venom allergy, SCIT using both insect venoms can be carried out concurrently [109, 111].

\section{Safety aspects of SCIT}

A systematic review and meta-analysis performed by the EAACI, and which included 160 studies on AIT, analyzed not only efficacy as a primary endpoint, but also secondary endpoints such as cost effectiveness and safety aspects [114].

The investigators found considerable heterogeneity in terms of the classifications used for reported side effects in the randomized controlled studies analyzed. In terms of the total number of side effects, a relative risk (RR) of 1.58 was found in the SCIT studies analyzed and an RR of 1.68 in the SLIT studies analyzed, indicating a generally comparable safety profile for the two modes of administration. An RR of 1.15 was found in the 15 SCIT studies in which treatmentrelated (allergic) systemic side effects were assessed in a pooled analysis. With regard to local reactions, the pooled analysis of nine SCIT studies yielded an RR of 2.21 .

The EAACI guideline on AIT in allergic rhinoconjunctivitis [31], on which this systematic review and meta-analysis was based, deems SCIT to be overall safe. However, it also provides clear recommendations on the implementation of and adherence to the relevant safety aspects. 


\section{Efficacy of SCIT in specific indications}

\section{SCIT in oral allergy syndrome}

Evidence on the efficacy of AIT using pollen allergens to treat oral allergy syndrome (OAS) is insufficient $[115,116]$. Further studies will have to be awaited before a conclusive assessment can be made $[1,116]$.

A randomized controlled study on 40 tree pollenallergic patients-20 treated with SCIT and 20 with SLIT-demonstrated an improvement in OAS in some patients [117]. A recent study on soy allergy sufferers using a recombinant folding variant of Bet $\mathrm{v} 1$ as an allergoid described an increase in the triggering allergen dose in oral challenge following 1 year of subcutaneous treatment [118]. Unfortunately, due to poor recruitment, the study failed to reach the case numbers needed to achieve the statistical power required for the primary endpoint. The product is currently no longer being evaluated by the company for approval. Another recent study on 60 patients with birch pollenrelated apple allergy showed clinical efficacy for recombinant Mal d 1 (the major apple allergen), but not for Bet v 1 [119]. In summary, SCIT for OAS is currently only indicated in the case of corresponding respiratory symptoms due to pollen allergens.

\section{SCIT in extrinsic atopic dermatitis}

A number of studies demonstrate the clinical effects of SCIT in patients with atopic dermatitis (AD) and corresponding type-1 sensitization to aeroallergens [120]. A randomized double-blind dose-response trial on SCIT in 89 adult patients with chronic $\mathrm{AD}$ and house dust mite sensitization revealed a significant improvement in their SCORAD (scoring atopic dermatitis) over the 1-year treatment period [121]. Another DBPC phase-II study (SCIT) on 168 adult patients showed a significant SCORAD improvement only in patients with severe AD [122].

A meta-analysis of the efficacy of AIT in AD investigated eight randomized controlled studies (two SLIT and six SCIT studies). Although this revealed a positive effect [123], the validity of this meta-analysis is limited due to the high heterogeneity of the studies, some with low patient numbers. In conclusion, it is clear from the current evidence that $\mathrm{AD}$ does not represent a contraindication to SCIT in the case of allergic respiratory symptoms requiring treatment.

\section{Documenting efficacy in daily practice}

Particularly in the routine follow-up of treatment for allergic respiratory diseases, real-life data are of considerable importance if reliable and comparable information on symptom severity before, during, and after treatment is to be obtained also outside clinical studies [124].
In order to document and evaluate this type of data, it is important that responses are not expressed in an arbitrary manner, but rather that they are assigned to a statistically measurable category. Any categorization of this kind must enable both an intra- and interindividual comparison of symptom severity. Visual analogue scales (VAS) have proven their worth as an instrument to assess the efficacy of AIT, since they are seen by test subjects as a continuum in which the same differences in symptom severity are assigned the same intervals on the VAS scale [125].

Particularly in combination with modern communication technology, e.g., smartphone apps, they provide a valuable tool to document symptom severity and treatment follow-up in allergic respiratory diseases; they are also well suited for this purpose due to the fact that they are simple to use, save time, and have low susceptibility to errors.

\section{Special features of SCIT in childhood}

In addition to the questions on the effective prevention and immunomodulation conferred by AIT, there is also a discussion on AIT in children and the extent to which subcutaneous administration is tolerated in this patient group, or whether sublingual immunotherapy should be preferred as a general principle. From a pediatric perspective, the authors consider the following points worthy of discussion:

1. Treatment involving subcutaneous injections is generally well accepted by children at school age if it has been well explained and presented to the parents and their children. Numerous other indications necessitate the use of sometimes frequent subcutaneous injections in children (diabetes, subcutaneous immunoglobulin administration, subcutaneous methotrexate injections). As such, the monthly administration of subcutaneous immunotherapy does not pose an insurmountable hurdle. On the contrary, many pediatricians feel that adherence is significantly better with subcutaneous compared with sublingual administration [126]. Having to take a tablet regularly every day often poses a greater challenge to children and adolescents in their daily routine than does the administration of one injection once a month.

2. The other aspect relates to documented efficacy in clinical studies. If one considers the evidence on SLIT and SCIT in childhood, one sees that a growing imbalance has developed here in recent years. Evidence from large DBPC studies is shifting increasingly towards SLIT, since approval has been sought only more recently for these newer products and more up-to-date studies were put forward to support the approval process. From the perspective of the practicing allergist, however, it cannot be automatically inferred that SCIT is less effective than SLIT. Clear advantages for SLIT in terms of evidence 
("an effect was demonstrated") do not automatically translate into a better effect. Meta-analyses that indirectly investigated the efficacy of SCIT and SLIT found no significant differences between the two modes of administration in terms of degree of efficacy. Studies that investigate the efficacy of SCIT and SLIT head-to-head with comparable preparations are desirable.

Conclusion on the two previous points The decision regarding which way of allergen application to favor in children and adolescents needs to be made on an individual basis. In addition to data on clinical efficacy, long-term effects, and tolerability, the treating physician's personal assessment of compliance and adherence as well as the patient's personal preferences need to be taken into account. It is undisputed that suitable recall systems need to be created for AIT performed according to medical standards, in order to keep the number of treatment discontinuations as low as possible. Only in this way can the potential of AIT to prevent the progression of sensitization, clinical allergy, and the onset or chronification of asthma be exploited to the full in younger patients as effectively as possible.

Acknowledgements The development of this publication was financially supported by Allergopharma, Reinbek, Germany through an independent medical writing grant. The views and opinions described in this publication do not necessarily reflect those of the grantor.

Conflict of interests L. Klimek has received research funds from the following companies: ALK-Abelló, Denmark; Allergopharma, Germany; Bionorica, Germany; Biomay, Austria; Boehringer Ingelheim, Germany; Circassia, USA; Stallergenes, France; HAL, The Netherlands; Allergy Therapeutics/Bencard, Great Britain/Germany; Hartington, Spain; Lofarma, Italy and MEDA, Sweden; MSD, USA; Novartis, Switzerland; LETI, Spain; ROXALL, Germany; GlaxoSmithKline, Great Britain; Cytos, Switzerland and Curalogic, Denmark. In addition, L. Klimek is a consultant for AllergyTherapeutics/Bencard, UK/Germany; HAL, The Netherlands; MEDA, Germany; and Boehringer Ingelheim, Germany. R. Brehler has received research funding from the following companies: Allergopharma, Bencard, and Biotech Tools, as well as Genentech, LETI, Novartis, and Circassia. He has also been a speaker for ALK-Abelló, Allergopharma, Almirall, Astra Zeneca, Bencard, the German Society for the Promotion of Dermatological Research and Training (Gesellschaft zur Förderung der Dermatologischen Forschung und Fortbildung), the German Society for Information and Organization (Gesellschaft für Information und Organisation), as well as GlaxoSmithKline, Dr. Pfleger, HAL, LETI, MedUpdate, Merck, Novartis, The Otorhinolaryngology Association (Oto-RhinoLaryngologischer Verein), Pierre Fabre, Pohl Boskamp, Stallergenes, and Thermo-Fischer. R. Brehler has worked as a consultant for: Allergopharma, Bencard, HAL, LETI, and Novartis. Eckard Hamelmann has received research funding from the German Federal Ministry of Education and Research (Bundesministerium für Bildung und Forschung, BMBF), North Rhine-Westphalia State Ministry of Research (Landesforschungsministerium Nordrhein-Westfalen) and the German Research Foundation (Deutsche Forschungs- gemeinschaft, DFG). He has also given lectures and been a consultant for Allergy Therapeutics/Bencard, Great Britain/ Germany; ALK-Abelló, Denmark; Allergopharma, Germany; Boehringer Ingelheim, Germany; GlaxoSmithKline, Great Britain; HAL Allergy, The Netherlands; LETI, Spain; Lofarma, Italy; Novartis, Switzerland, and Stallergenes, France. Matthias Kopp received fees from ALK-Abelló, Allergopharma, LETI, and Novartis, as well as from Boehringer Ingelheim, Chiesi, GlaxoSmithKline, and Infectopharm during the period of this study. J. Ring has served on advisory boards for ALK-Abelló, Allergopharma, Bencard, HAL, and Novartis. R. Treudler states that she received fees from ALK-Abelló and LETI during the period of this study. Over and above this study, she has received fees from Sanofi Aventis and Novartis. T. Jakob has received the following grants and funding for projects other than the work submitted here: research grants and fees from ALK-Abelló, Germany; fees and nonfinancial support from Bencard/Allergy Therapeutics, Germany; research grants, fees, and nonfinancial support from Thermo Fisher Scientific, Sweden, as well as fees from Stallergenes, Germany; research grants, fees, and nonfinancial support from Allergopharma, Germany, and research grants and fees from Novartis, Germany. T. Jakob has also received fees from Springer Nature, as well as nonfinancial support from the German Society for Allergology and Clinical Immunology (Deutsche Gesellschaft für Allergie und klinische Immunologie). O. Pfaar reports grants and personal fees from ALK-Abelló, grants and personal fees from Allergopharma, grants and personal fees from Stallergenes Greer, grants and personal fees from HAL Allergy Holding B.V./HAL Allergie $\mathrm{GmbH}$, grants and personal fees from Bencard Allergie $\mathrm{GmbH} /$ Allergy Therapeutics, grants and personal fees from Lofarma, grants from Biomay, grants from Nuvo, grants from Circassia, grants and personal fees from ASIT Biotech Tools S.A., grants and personal fees from Laboratorios LETI/LETI Pharma, personal fees from Novartis Pharma, personal fees from MEDA Pharma, grants and personal fees from Anergis S.A., personal fees from Mobile Chamber Experts (a GA2LEN Partner), personal fees from Pohl-Boskamp, personal fees from Indoor Biotechnologies, grants from Glaxo Smith Kline, personal fees from Astellas Pharma Global, outside the submitted work. M. Worm reports fees for advisory boards and lecture activities from Allergopharma GmbH \& Co. KG, ALKAbelló Arzneimittel GmbH, Meda Pharma GmbH \& Co. KG, HAL Allergie $\mathrm{GmbH}$, Stallergenes $\mathrm{GmbH}$, Bencard Allergie $\mathrm{GmbH}$, LETI Pharma GmbH, outside the submitted work.

Open Access This article is distributed under the terms of the Creative Commons Attribution 4.0 International License (http://creativecommons.org/licenses/by/4.0/), which permits unrestricted use, distribution, and reproduction in any medium, provided you give appropriate credit to the original author(s) and the source, provide a link to the Creative Commons license, and indicate if changes were made.

\section{References}

1. Pfaar O, Bachert C, Bufe A, Buhl R, Ebner C, Eng P, et al. Guideline on allergen-specific immunotherapy in IgEmediated allergic diseases. Allergo J Int. 2014;23:282-319.

2. UlrichJT, Myers KR. MonophosphoryllipidA as anadjuvant. Past experiences and new directions. Pharm Biotechnol. 1995;6:495-524.

3. Klimek L, Schmidt-Weber CB, Kramer MF, Skinner MA, Heath MD. Clinical use of adjuvants in allergen-immunotherapy. Expert Rev Clin Immunol. 2017;13:599-610. 
4. Klimek L, Willers J, Schendzielorz P, Kundig TM, Senti G. Immunotherapy of allergic rhinitis without allergens? : new options for immunomodulation by vaccination with viruslike particles and CpG motifs. HNO. 2013;61:826-33.

5. Ring J, Gutermuth J. 100 years of hyposensitization: history of allergen-specific immunotherapy (ASIT). Arerugi. 2011;66:713-24.

6. Bergmann KC, Ring J, editors. History of Allergy. Chemical Immunology and Allergy. Basel: Karger; 2014.

7. Noon L. Prophylactic inoculation against hay fever. Lancet. 1911;177:1572-3.

8. Akdis M, Akdis CA. Mechanisms of allergen-specific immunotherapy. JAllergy Clin Immunol. 2007;119:780-91.

9. Bellinghausen I, Knop J, Saloga J. The role of interleukin 10 in the regulation of allergic immune responses. Int Arch Allergy Immunol. 2001;126:97-101.

10. Bellinghausen I, Klostermann B, Böttcher I, Knop J, Saloga J. Importance of the inducible costimulator molecule for the induction of allergic immune responses and its decreased expression on $\mathrm{T}$ helper cells after venom immunotherapy. Immunology. 2004;112:80-6.

11. Francis JN, Till SJ, Durham SR. Induction of IL-10+CD4+ CD25+ T cells by grass pollen immunotherapy. JAllergy Clin Immunol. 2003;111:1255-61.

12. Jutel M, Akdis M, Budak F, Aebischer-Casaulta C, Wrzyszcz $\mathrm{M}$, Blaser K, et al. IL-10 and TGF-beta cooperate in the regulatory $\mathrm{T}$ cell response to mucosal allergens in normal immunity and specific immunotherapy. Eur J Immunol. 2003;33:1205-14.

13. Wing K, Sakaguchi S. Regulatory T cells as potential immunotherapy in allergy. Curr Opin Allergy Clin Immunol. 2006;6:482-8.

14. Bellinghausen I, König B, Böttcher I, Knop J, Saloga J. Regulatory activity of human CD4 CD25 T cells depends on allergen concentration, type of allergen and atopy status of the donor. Immunology. 2005;116:103-11.

15. Ling EM, Smith T, Nguyen XD, Pridgeon C, Dallman M, Arbery J, et al. Relation of CD4+CD25+ regulatory T-cell suppression of allergen-driven T-cell activation to atopic status and expression of allergic disease. Lancet. 2004;363:608-15.

16. Passalacqua G, Durham SR, Global Allergy and Asthma European Network. Allergic rhinitis and its impact on asthma update: allergen immunotherapy. J Allergy Clin Immunol. 2007;119:881-91.

17. Wachholz PA, Durham SR. Mechanisms of immunotherapy: IgG revisited. Curr Opin Allergy Clin Immunol. 2004;4:313-8.

18. Novak N. Targeting dendritic cells in allergen immunotherapy. Immunol Allergy Clin North Am. 2006;26:307-19.

19. Durham SR, Varney VA, Gaga M, Jacobson MR, Varga EM, Frew AJ, et al. Grass pollen immunotherapy decreases the number of mast cells in the skin. Clin Exp Allergy. 1999;29:1490-6.

20. Pierkes M, BellinghausenI, Hultsch T, MetzG, KnopJ, Saloga J. Decreased release of histamine and sulfidoleukotrienes by human peripheral blood leukocytes after wasp venom immunotherapy is partially due to induction of IL-10 and IFN-gamma production of T cells. J Allergy Clin Immunol. 1999;103:326-32.

21. Calderon MA, Alves B, Jacobson M, Hurwitz B, Sheikh A, Durham S. Allergen injection immunotherapy for seasonal allergic rhinitis. Cochrane Database Syst Rev. 2007; https:// doi.org/10.1002/14651858.CD001936.pub2.

22. Radulovic S, Calderon MA, Wilson D, Durham S. Sublingual immunotherapy for allergic rhinitis. Cochrane Database Syst Rev. 2010; https://doi.org/10.1002/ 14651858.CD002893.
23. Walker SM, Durham SR, Till SJ, Roberts G, Corrigan CJ, Leech SC, et al. Immunotherapy for allergic rhinitis. Clin ExpAllergy. 2011;41:1177-200.

24. Corrigan CJ, Kettner J, Doemer C, Cromwell O, Narkus A, Study Group.. Efficacy and safety of preseasonal-specific immunotherapy with an aluminium-adsorbed six-grass pollen allergoid. Arerugi. 2005;60:801-7.

25. DuBuske LM, FrewAJ, HorakF, Keith PK, Corrigan CJ, Aberer $\mathrm{W}$, et al. Ultrashort-specific immunotherapy successfully treats seasonal allergic rhinoconjunctivitis to grass pollen. Allergy Asthma Proc. 2011;32:239-47.

26. Pfaar O, Urry Z, Robinson DS, Sager A, Richards D, Hawrylowicz CM, et al. A randomized placebo-controlled trial of rush preseasonal depigmented polymerized grass pollen immunotherapy. Allergy. 2012;67:272-9.

27. Pfaar O, Robinson DS, Sager A, Emuzyte R. Immunotherapy with depigmented-polymerized mixed tree pollen extract: a clinical trial and responder analysis. Allergy. 2010;65:1614-21.

28. Zielen S, Kardos P, Madonini E. Steroid-sparing effects with allergen-specific immunotherapy in children with asthma: a randomized controlled trial. J Allergy Clin Immunol. 2010;126:942-9.

29. Tworek D, Bochenska-Marciniak M, Kuprys-Lipinska I, Kupczyk M, Kuna P. Perennial is more effective than preseasonal subcutaneousimmunotherapyin the treatment of seasonal allergic rhinoconjunctivitis. Am J Rhinol Allergy. 2013;27:304-8.

30. Pfaar O, Lang S, Pieper-Fürst U, Astvatsatourov A, Gerich F, Klimek L, et al. Ultra-short-course booster is effective in recurrent grass pollen-induced allergic rhinoconjunctivitis. Allergy. 2018;73:187-95.

31. Roberts G, Pfaar O, Akdis CA, Ansotegui IJ, Durham SR, Gerth van Wijk R, et al. EAACI Guidelines on Allergen Immunotherapy: Allergic rhinoconjunctivitis. Allergy. 2018;73:765-98.

32. Canonica GW, Baena-Cagnani CE, Bousquet J, Bousquet PJ, Lockey RF, Malling HJ, et al. Recommendations for standardization of clinical trials with Allergen Specific Immunotherapy for respiratory allergy. A statement of a World Allergy Organization (WAO) taskforce. Arerugi. 2007;62:317-24.

33. Pfaar O, Demoly P, Gerth van Wijk R, Bonini S, Bousquet J, Canonica GW, et al. European Academy of Allergy and Clinical Immunology. Recommendations for the standardization of clinical outcomes used in allergen immunotherapy trials for allergic rhinoconjunctivitis: an EAACI Position Paper. Allergy. 2014;69:854-67.

34. Englert L, May S, Kaul S, Vieths S. The therapy allergens ordinance ("Therapieallergene-Verordnung"). Background and effects. Bundesgesundheitsblatt. 2012;55:351-7.

35. Dolz I, Martinez-Cócera C, Bartolomé JM, Cimarra M. A double-blind, placebo-controlled study of immunotherapy with grass-pollen extract Alutard SQ during a 3-year period with initial rush immunotherapy. Allergy. 1996;51:489-500.

36. Frew AJ, Powell RJ, Corrigan CJ, Durham SR, UK Immunotherapy Study Group. Efficacy and safety of specific immunotherapy with SQ allergen extract in treatment-resistant seasonal allergic rhinoconjunctivitis. J Allergy Clin Immunol. 2006;117:319-25.

37. Varney VA, Gaga M, Frew AJ, Aber VR, Kay AB, Durham SR. Usefulness of immunotherapy in patients with severe summer hay fever uncontrolled by antiallergic drugs. BMJ. 1991;302:265-9.

38. Roberts G, Hurley C, Turcanu V, Lack G. Grass pollen immunotherapyas an effective therapy for childhood seasonal allergic asthma. J Allergy Clin Immunol. 2006;117:263-8. 
39. Kepil Özdemir S, Sin BA, Güloğlu D, İkincioğulları A, Gençtürk Z, Misırlıgil Z. Short-term preseasonal immunotherapy: is early clinical efficacy related to the basophil response? Int Arch Allergy Immunol. 2014;164:237-45.

40. Zidarn M, Košnik M, Šilar M, Bajrović N, Korošec P. Sustained effect of grass pollen subcutaneous immunotherapy on suppression of allergen-specific basophil response; a real-life, nonrandomized controlled study. Allergy. 2015;70:547-55.

41. Klimek L, Uhlig J, Mösges R, Rettig K, Pfaar O. A high polymerized grass pollen extract is efficacious and safe in a randomized double-blind, placebo-controlled study using a novel up-dosing cluster-protocol. Allergy. 2014;69:1629-38.

42. Alvarez-Cuesta E, Aragoneses-Gilsanz E, Martín-Garcia C, Berges-Gimeno P, Gonzalez-Mancebo E, Cuesta-Herranz J. Immunotherapy with depigmented glutaraldehyde-polymerized extracts: changes in quality of life. Clin Exp Allergy. 2005;35:572-8.

43. Drachenberg KJ, Wheeler AW, Stuebner P, Horak F. A welltolerated grass pollen-specific allergy vaccine containing a novel adjuvant, monophosphoryl lipid A, reduces allergic symptoms after only four preseasonal injections. Allergy. 2001;56:498-505.

44. Bozek A, Kolodziejczyk K, Krajewska-Wojtys A, Jarzab J. Pre-seasonal, subcutaneous immunotherapy: a double-blinded, placebo-controlled study in elderly patients with an allergy to grass. Ann Allergy Asthma Immunol. 2016;116:156-61.

45. Arvidsson MB, Löwhagen O, RakS. Effect of 2-year placebocontrolled immunotherapy on airway symptoms and medication in patients with birch pollen allergy. J Allergy Clin Immunol. 2002;109:777-83.

46. Bødtger U, Poulsen LK, Jacobi HH, Malling HJ. The safety and efficacy of subcutaneous birch pollen immunotherapy-a one-year, randomised, double-blind, placebo-controlled study. Allergy. 2002;57:297-305.

47. BaldaBR, WolfH, Baumgarten C, KlimekL, RaspG, KunkelG, et al. Tree-pollen allergy is efficiently treated by short-term immunotherapy (STI) with seven preseasonal injections of molecular standardized allergens. Allergy. 1998;53:740-8.

48. Höiby AS, Strand V, Robinson DS, Sager A, Rak S. Efficacy, safety, and immunological effects of a 2-year immunotherapy with Depigoid birch pollen extract: a randomized, double-blind, placebo-controlled study. Clin Exp Allergy. 2010;40:1062-70.

49. Drachenberg KJ, Heinzkill M, Urban E. Kurzzeit-Immuntherapie mit Baumpollen-Allergoiden und dem Adjuvans Monophosphoryl Lipid A-Ergebnisse einer randomisierten, doppelblinden, plazebokontrollierten Multicenterstudie. Allergologie. 2002;25:466-74.

50. Ceuppens JL, Bullens D, Kleinjans H, van der Werf J, PURETHAL Birch Efficacy Study Group. Immunotherapy with a modified birch pollen extract in allergic rhinoconjunctivitis: clinical and immunological effects. Clin Exp Allergy. 2009;39:1903-9.

51. Klimek L, Gröger M, Becker S. Milbenallergie im HNOBereich: Bedeutung, Diagnostik und Therapieoptionen. Laryngorhinootologie. 2018;97:56-69.

52. Fernández-Caldas E. Towards a more complete standardization of mite allergen extracts. Int Arch Allergy Immunol. 2013;160:1-3.

53. Vidal-Quist JC, Ortego F, Castañera P, Hernández-Crespo P. Quality control of house dust mite extracts by broadspectrum profiling of allergen-related enzymatic activities. Allergy. 2017;72:425-34.
54. Carnés J, Iraola V, Cho SH, Esch RE. Mite allergen extracts and clinical practice. Ann Allergy Asthma Immunol. 2017;118:249-56.

55. Casset A, Mari A, Purohit A, Resch Y, Weghofer M, Ferrara $\mathrm{R}$, et al. Varying allergen composition and content affects the in vivo allergenic activity of commercial Dermatophagoides pteronyssinus extracts. Int Arch Allergy Immunol. 2012;159:253-62.

56. Haugaard L, Dahl R, Jacobsen L. A controlled dose-response study of immunotherapy with standardized, partially purified extract of house dust mite: clinical efficacy and side effects. JAllergy Clin Immunol. 1993;91:709-22.

57. Pfaar O, Nell MJ, Boot JD, Versteeg SA, van Ree R, Roger A, et al. Arandomized, 5-arm dose finding study with a miteallergoid SCIT in allergic rhinoconjunctivitis patients. Allergy. 2016;71:967-76.

58. Moreno V, Alvariño M, Rodríguez F, Roger A, Peña-Arellano MI, Lleonart R, et al. Randomized dose-response study of subcutaneous immunotherapy with a Dermatophagoides pteronyssinus extract in patients with respiratory allergy. Immunotherapy. 2016;8:265-77.

59. Bożek A, Kołodziejczyk K, Kozłowska R, Canonica GW. Evidence of the efficacy and safety of house dust mite subcutaneous immunotherapy in elderly allergic rhinitis patients: a randomized, double-blind placebo-controlled trial. Clin Transl Allergy. 2017;7:43.

60. Lozano J, Cruz MJ, Piquer M, Giner MT, Plaza AM. Assessing the efficacy of immunotherapy with a glutaraldehydemodified house dust mite extract in children by monitoring changes in clinical parameters and inflammatory markers in exhaled breath. Int Arch Allergy Immunol. 2014;165:140-7.

61. Yukselen A, Kendirli SG, Yilmaz M, Altintas DU, Karakoc GB. Effect of one-year subcutaneous and sublingual immunotherapy on clinical and laboratory parameters in children with rhinitis and asthma: a randomized, placebocontrolled, double-blind, double-dummy study. Int Arch Allergy Immunol. 2012;157:288-98.

62. Ameal A, Vega-Chicote JM, Fernndez S, Miranda A, Carmona MJ, Rondn MC et al. Double-blind and placebocontrolled study to assess efficacy and safety of a modified allergen extract of Dermatophagoides pteronyssinus in allergic asthma. Allergy 2005:60:1178-83

63. Garcia-Robaina J-C, Sánchez I, de la Torre F, FernándezCaldas E, Casanovas M. Successful management of mite-allergic asthma with modified extracts of Dermatophagoides pteronyssinus and Dermatophagoides farinae in a doubleblind, placebo-controlled study. J Allergy Clin Immunol 2006;118:1026-32

64. Metzger WJ, Dorminey HC, Richerson HB, Weiler JM, Donnelly A, Moran D. Clinical and immunologic evaluation of glutaraldehyde-modified tyrosine-adsorbed shortragweed extract: a double-blind, placebo-controlled trial. J Allergy Clin Immunol. 1981;68:442-8.

65. Blumberga G, Groes L, Dahl R. SQ-standardized house dust mite immunotherapy as an immunomodulatory treatment in patients with asthma. Allergy. 2011;66:178-85.

66. Gallego MT, Iraola V, Himly M, Robinson DS, Badiola C, García-Robaina JC, et al. Depigmented and polymerised house dust mite allergoid: allergen content, induction of IgG4 and clinical response. Int Arch Allergy Immunol. 2010;153:61-9.

67. Riechelmann H, Schmutzhard J, van der Werf JF, Distler A, Kleinjans HA. Efficacy and safety of a glutaraldehydemodified house dust mite extract in allergic rhinitis. Am J RhinolAllergy. 2010;24:e104-9. 
68. Wang H, Lin X, Hao C, Zhang C, Sun B, Zheng J, et al. A double-blind, placebo-controlled study of house dust mite immunotherapy in Chinese asthmatic patients. Allergy. 2006;61:191-7.

69. Dokic D, SchnitkerJ, Narkus A, CromwellO, FrankE. Clinical effects of specific immunotherapy: a two-year doubleblind, placebo-controlled study with a one year follow-up. Prilozi. 2005;26:113-29.

70. Varney VA, Tabbah K, Mavroleon G, Frew AJ. Usefulness of specific immunotherapy in patients with severe perennial allergic rhinitis induced byhouse dustmite: a double-blind, randomized, placebo-controlled trial. Clin Exp Allergy. 2003;33:1076-82.

71. Olsen OT, Larsen KR, Jacobsan L, Svendsen UG. A 1-year, placebo-controlled, double-blind house-dustmite immunotherapy study in asthmatic adults. Allergy. 1997;52:853-9.

72. Ewan PW,Alexander MM, SnapeC, IndPW,AgrellB, Dreborg S. Effective hyposensitization in allergic rhinitis using a potent partially purified extract of house dust mite. Clin Allergy. 1988;18:501-8.

73. Armentia-Medina A, Tapias JA, Martin JF, Ventas P, FernándezA. Immunotherapy with the storage mitelepidoglyphus destructor. Allergol Immunopathol. 1995;23:211-23.

74. Buters J, Alberternst B, Nawrath S, Wimmer M, TraidlHoffmann C, Starfinger U, et al. Ambrosia artemisiifolia (ragweed) in Germany-current presence, allergological relevance and containment procedures. Allergo J Int. 2015;24:108-20.

75. Lake IR, Jones NR, Agnew M, Goodess CM, Giorgi F, Hamaoui-Laguel L, et al. Climate Change and Future Pollen Allergy in Europe. Environ Health Perspect. 2017;125:385-91.

76. Patel P, Holdich T, Fischer von Weikersthal-Drachenberg KJ, Huber B. Efficacy of a short course of specific immunotherapy in patients with allergic rhinoconjunctivitis to ragweed pollen. J Allergy Clin Immunol. 2014;133:121-129.e1-2.

77. Norman PS, Lichtenstein LM, Kagey-Sobotka A, Marsh DG. Controlled evaluation of allergoid in the immunotherapy of ragweed hay fever. J Allergy Clin Immunol. 1982;70:248-60.

78. Grammer LC, Shaughnessy MA, Bernhard MI, Finkle SM, Pyle HR, Silvestri L, et al. The safety and activity of polymerized ragweed: a double-blind, placebo-controlled trial in 81 patients with ragweed rhinitis. J Allergy Clin Immunol. 1987;80:177-83.

79. Iliopoulos O, Proud D, Adkinson NF Jr, Creticos PS, Norman PS, Kagey-Sobotka A, et al. Effects of immunotherapy on the early, late, and rechallenge nasal reaction to provocation withallergen: changesininflammatorymediators and cells. JAllergy Clin Immunol. 1991;87:855-66.

80. Brunet C, Bédard PM, Lavoie A, Jobin M, Hébert J. Allergic rhinitis to ragweed pollen. I. Reassessment of the effects of immunotherapy on cellular and humoral responses. JAllergy Clin Immunol. 1992;89:76-86.

81. Mirone C, Albert F, Tosi A, Mocchetti F, Mosca S, Giorgino $\mathrm{M}$, et al. Efficacy and safety of subcutaneous immunotherapy with a biologically standardized extract of Ambrosia artemisiifolia pollen: a double-blind, placebo-controlled study. Clin Exp Allergy. 2004;34:1408-14.

82. Creticos PS, Reed CE, Norman PS, Khoury J, Adkinson NF Jr, Buncher CR, et al. Ragweed immunotherapy in adult asthma. NEngl J Med. 1996;334:501-6.

83. Guerra F, Daza JC, Almeda E. Immunotherapy with a depigmented, polymerized vaccine of Olea europaea pollen allergens. Significantly reduces specific bronchial and skin test reactivity in sensitized patients after one year of treatment. J InvestigAllergol Clin Immunol. 2003;13:108-17.
84. Gokmen NM,ErsoyR, GulbaharO, ArdenizO, SinA, UnselM, et al. Desensitization effect of preseasonal seven-injection allergoid immunotherapy with olive pollen on basophil activation: the efficacy of olive pollen-specific preseasonal allergoid immunotherapy on basophils. Int Arch Allergy Immunol. 2012;159:75-82.

85. Ferrer M, Burches E, Peláez A, Muñoz A, Hernández D, Basomba A, et al. Double-blind, placebo-controlled study of immunotherapy with Parietaria judaica: clinical efficacy and tolerance. J Investig Allergol Clin Immunol. 2005; 15:283-92.

86. Crimi N, Gotti LF, Mangano G, Paolino G, Mastruzzo C, Vancheri C, et al. A randomized, controlled study of specific immunotherapy in monosensitized subjects with seasonal rhinitis: effect on bronchial hyperresponsiveness, sputuminflammatorymarkersand development of asthma symptoms. Ann Ital Med Int. 2004;19:98-108.

87. Ortolani C, Pastorello EA, Incorvaia C, Ispano M, Farioli L, Zara C, et al. A double-blind, placebo-controlled study of immunotherapy with an alginate-conjugated extract of Parietaria judaica in patients with Parietaria hay fever. Allergy. 1994;49:13-21.

88. Ariano R, KroonAM,Augeri G, Canonica GW, Passalacqua G. Long-term treatment with allergoid immunotherapy with Parietaria. Clinical and immunologic effects in a randomized, controlled trial. Allergy. 1999;54:313-9.

89. Tari MG, Mancino M, Ghezzi E, Frank E, Cromwell O. Immunotherapy with an alum-adsorbed Parietaria-pollen allergoid: a 2-year, double-blind, placebo-controlled study. Allergy. 1997;52:65-74.

90. Charpin D, Gouitaa M, Dron-Gonzalvez M, Fardeau MF, Massabie-Bouchat YP, Hugues B, et al. Immunotherapy with an aluminum hydroxide-adsorbed Juniperus ashei foreign pollen extract in seasonal indigenous cypress pollen rhinoconjunctivitis. A double-blind, placebo-controlled study. Int Arch Allergy Immunol. 2007;143:83-91.

91. Varney VA, Edwards J, Tabbah K, Brewster H, Mavroleon G, Frew AJ. Clinical efficacy of specific immunotherapy to cat dander: a double-blind placebo-controlled trial. Clin Exp Allergy. 1997;27:860-7.

92. Ohman JL Jr, Findlay SR, Leitermann KM. Immunotherapy in cat-induced asthma. Double-blind trial with evaluation of in vivo and in vitro responses. J Allergy Clin Immunol. 1984;74:230-9.

93. Taylor WW, Ohman JL Jr, Lowell FC. Immunotherapy in cat-induced asthma. Double-blind trial with evaluation of bronchial responses to cat allergen and histamine. J Allergy Clin Immunol. 1978;61:283-7.

94. Patel D, Couroux P, Hickey P, SalapatekAM, Laidler P, Larché $\mathrm{M}$, et al. Fel d 1-derived peptide antigen desensitization shows a persistent treatment effect 1 year after the start of dosing: a randomized, placebo-controlled study. J Allergy Clin Immunol. 2013;131:103-109.e1-7.

95. Gerth van Wijk R. Positive and negative AIT trials: What makes the difference? Allergo J Int. 2018;27:167-72.

96. Frew AJ, Pfaar O. Placebo effects in allergen immunotherapy: an experts' opinion. Allergo J Int. 2018;27:162-6.

97. Fukutomi Y, Taniguchi M. Sensitization to fungal allergens: resolved and unresolved issues. Allergol Int. 2015;64:321-31.

98. Coop CA. Immunotherapy for mold allergy. Clin RevAllergy Immunol. 2014;47:289-98.

99. Kuna P, Kaczmarek J, Kupczyk M. Efficacy and safety of immunotherapy for allergies to Alternaria alternata in children. J Allergy Clin Immunol. 2011;127:502-508.e1-6. 
100. Ostergaard PA, Kaad PH, Kristensen T. A prospective study on the safety of immunotherapy in children with severe asthma. Allergy. 1986;41:588-93.

101. Kaad PH, Ostergaard PA. The hazard of mould hyposensitization in children with asthma. Clin Allergy. 1982;12:317-20.

102. Tabar AI, Lizaso MT, García BE, Echechipía S, Olaguibel JM, RodríguezA. Tolerance of immunotherapy with a standardized extract of Alternaria tenuis in patients with rhinitis and bronchial asthma. J Investig Allergol Clin Immunol. 2000;10:327-33.

103. Bozek A, Pyrkosz K. Immunotherapy of mold allergy: a review. Hum Vaccin Immunother. 2017;13:2397-401.

104. Tabar AI, Lizaso MT, García BE, Gómez B, Echechipía S, Aldunate MT, et al. Double-blind, placebo-controlled study of Alternaria alternata immunotherapy: clinical efficacy and safety. Pediatr Allergy Immunol. 2008;19:67-75.

105. Kiliç M, Altintaş DU, Yilmaz M, Bingöl-Karakoç G, Burgut R, Güneşer-Kendirli S. Evaluation of efficacy of immunotherapy in children with asthma monosensitized to Alternaria. TurkJ Pediatr. 2011;53:285-94.

106. Horst M, Hejjaoui A, Horst V, Michel FB, Bousquet J. Double-blind, placebo-controlled rush immunotherapy with a standardized Alternaria extract. J Allergy Clin Immunol. 1990;85:460-72.

107. Dreborg S, Agrell B, Foucard T, Kjellman NI, Koivikko A, Nilsson S. A double-blind, multicenter immunotherapy trial in children, using a purified and standardized Cladosporium herbarum preparation. I. Clinical results. Allergy. 1986;41:131-40.

108. Malling HJ, Dreborg S, Weeke B. Diagnosis and immunotherapy of mould allergy. V. Clinical efficacy and side effects of immunotherapy with Cladosporium herbarum. Allergy. 1986;41:507-19.

109. Przybilla B, RuëffF, Walker A, AbererW, BauerCP, BerdelD, et al. Diagnose und Therapie der Bienen- und Wespengiftallergie. Allergologie. 2012;35:563-89.

110. Dhami S, Zaman H, Varga EM, Sturm GJ, Muraro A, Akdis $\mathrm{CA}$, et al. Allergen immunotherapy for insect venom allergy: a systematic review and meta-analysis. Allergy. 2017;72:342-65.

111. Sturm GJ, Varga EM, Roberts G, Mosbech H, Bilò MB, Akdis $\mathrm{CA}$, et al. EAACI guidelines on allergen immunotherapy: hymenoptera venom allergy. Arerugi. 2018;73:744-64.

112. Hunt KJ, Valentine MD, Sobotka AK, Benton AW, Amodio FJ, Lichtenstein LM. A controlled trial of immunotherapy in insecthypersensitivity. NEngl J Med. 1978;299:157-61.

113. Schumacher MJ, Tveten MS, Egen NB. Rate and quantity of delivery of venom from honeybee stings. J Allergy Clin Immunol. 1994;93:831-5.

114. Dhami S, Nurmatov U, Arasi S, Khan T, Asaria M, Zaman $\mathrm{H}$, et al. Allergen immunotherapy for allergic rhinoconjunctivitis: A systematic review and meta-analysis. Allergy. 2017;72:1597-631.

115. Mari A, Ballmer-Weber BK, Vieths S. The oral allergy syndrome: improved diagnostic and treatment methods. Curr Opin Allergy Clin Immunol. 2005;5:267-73.
116. Treudler R, Klimek L. Allergen immunotherapy in oral allergy syndrome: What kind of evidence do we have? Allergo J Int. 2019;28(2):50-6.

117. Mauro M, Russello M, Incorvaia C, Gazzola G, Frati F, Moingeon P, et al. Birch-apple syndrome treated with birch pollen immunotherapy. Int Arch Allergy Immunol. 2011;156:416-22.

118. Treudler R, Franke A, Schmiedeknecht A, Ballmer-Weber B, Worm M, Werfel T, et al. BASALIT trial: double-blind placebo-controlled allergen immunotherapy with rBet $\mathrm{v}$ 1-FV in birch-related soya allergy. Allergy. 2017;72:1243-53.

119. Kinaciyan T, Nagl B, Faustmann S, Frommlet F, Kopp S, Wolkersdorfer M, et al. Efficacy and safety of 4 months of sublingual immunotherapy with recombinant Mal d 1 and Bet $\mathrm{v} 1$ in patients with birch pollen-related apple allergy. JAllergy Clin Immunol. 2018;141:1002-8.

120. Bussmann C, Böckenhoff A, Henke H, Werfel T, Novak N. Does allergen-specific immunotherapy represent a therapeutic option for patients with atopic dermatitis? J Allergy Clin Immunol. 2006;118:1292-8.

121. Werfel T, Breuer K, RueffF, Przybilla B, Worm M, Grewe M, et al. Usefulness of specific immunotherapy in patients with atopic dermatitis and allergic sensitization to house dust mites: a multi-centre, randomized, dose-response study. Allergy. 2006;61:202-5.

122. Novak N, Bieber T, Hoffmann M, Fölster-Holst R, Homey B, Werfel T et al. Efficacy and safety of subcutaneous allergenspecific immunotherapy with depigmented polymerized mite extract in atopic dermatitis. J Allergy Clin Immunol 2012;130:925-31.e4

123. Bae JM, Choi YY, Park CO, Chung KY, Lee KH. Efficacy of allergen-specific immunotherapy for atopic dermatitis: a systematic review and meta-analysis of randomized controlled trials. JAllergy Clin Immunol 2013;132:110-7

124. Weschenfelder AK, Klimek L, Mülleneisen N, Renz H, Wehrmann W, Werfel $\mathrm{T}$ et al. Course of respiratory allergy by treatment strategy based on German routine data. Allergo J Int 2017;26:195-203

125. Klimek L, Bergmann KC, Biedermann T, Bousquet J, Hellings $\mathrm{P}$, Jung $\mathrm{K}$ et al. Visual analogue scales (VAS): Measuring instruments for the documentation of symptoms and therapy monitoring in cases of allergic rhinitis in everyday health care: Position Paper of the German Society of Allergology (AeDA) and the German Society of Allergy and Clinical Immunology (DGAKI), ENT Section, in collaboration with the working group on Clinical Immunology, Allergology and Environmental Medicine of the German Society of Otorhinolaryngology, Head and NeckSurgery (DGHNOKHC). Allergo J Int 2017;26:16-24

126. Manzotti G, Riario-Sforza GG, Dimatteo M, Scolari C, Makri $\mathrm{E}$, Incorvaia C. Comparing the compliance to a short schedule of subcutaneous immunotherapy and to sublingual immunotherapy during three years of treatment. Eur Ann Allergy Clin Immunol 2016;48:224-7 